\title{
Can Amazon.com Reviews Help to Assess the Wider Impacts of Books? ${ }^{1}$
}

Kayvan Kousha

Statistical Cybermetrics Research Group, School of Mathematics and Computer Science, University of Wolverhampton, Wulfruna Street, Wolverhampton WV1 1LY, UK.

Tel. +44 1902 321476. Fax +44 1902 321478, Email: k.kousha@wlv.ac.uk

Mike Thelwall

Statistical Cybermetrics Research Group, School of Mathematics and Computer Science, University of Wolverhampton, Wulfruna Street, Wolverhampton WV1 1LY, UK.

Tel. +44 1902 321470. Fax +44 1902 321478, Email: m.thelwall@wlv.ac.uk

Although citation counts are often used to evaluate the research impact of academic publications, they are problematic for books that aim for educational or cultural impact. To fill this gap, this article assesses whether a number of simple metrics derived from Amazon.com reviews of academic books could give evidence about their impacts. Based upon a set of 2,739 academic monographs from 2008 and a set of 1,305 best-selling books in 15 Amazon.com academic subject categories, the existence of significant but low or moderate correlations between citations and numbers of reviews, combined with other evidence, suggests that online book reviews tend to reflect the wider popularity of a book rather than its academic impact, although there are substantial disciplinary differences. Metrics based upon online reviews are therefore recommended for the evaluation of books that aim at a wide audience inside or outside academia when it is important to capture the broader impacts of educational or cultural activities and when they cannot be manipulated in advance of the evaluation.

\section{Introduction}

Although citation analysis is commonly used to assess the impact of published research, it is dependent on the availability of citation indexes with adequate and appropriate coverage. For book impact assessment, this is a problem because other books are a logical source of citations to books in book based fields like history where they seem to be more numerous than citations from articles (Kousha, Thelwall, \& Rezaie, 2011) and book-to-book citations may also be useful for research assessment purposes in other fields. Nevertheless, citations from books have historically been largely ignored by citation indexes and even today relatively few books are indexed by Scopus and the Web of Science. This is a particular problem from the perspective of assessing impact in the social sciences and the humanities (e.g., Hicks, 1999; Huang \& Chang, 2008; Nederhof, 2006), where books and monographs play an important role in research. For instance, about a third of submissions to the 2008 UK Research Assessment Exercise (RAE) in social sciences and humanities subject areas were books, in comparison to only $1 \%$ in the

1. This is a preprint of an article to be published in the Journal of the Association for Information Science and Technology (C) copyright 2014 John Wiley \& Sons, Inc. 
sciences (Kousha, Thelwall, \& Rezaie, 2011). Perhaps in response to this issue, both Thomson Reuters and Elsevier have started to add citations from selected academic books to their citation indexes (the Book Citation Index and Scopus Book Search, respectively). Nevertheless, their coverage of books is still low and this may cause problems for citation impact assessment in book-based fields (e.g., Gorraiz, Purnell, \& Glänzel, 2013; Torres-Salinas et al., 2012,2013).Google Books automatic searches and filtering provides a way to extract citations from a huge collection of digitised books but may give poor results for books with very short titles (Kousha \& Thelwall, 2009; Kousha \& Thelwall, 2014), and the results may not reflect all the different types of intellectual impacts that academic books can have.

A more fundamental problem with using citation counts to evaluate the impact of books is that different types of books (e.g., monographs, chapters, textbooks, specialist books and books aimed at the wider public) can be valuable in research, teaching and other professional activities in ways that are unlikely to be fully reflected by citation counts. In this context, expert peer review might be more reliable than citation counting for the evaluation of books, if the reviewers are able to cope with the different goals and audiences for academic books. Several countries are using peer review or "peer review informed by metrics" to monitor the research outputs (including books) of universities, departments or subject areas (e.g., UK, Australia, Italy, Portugal and Poland) (Hicks, 2012, p. 255), although supplementing peer review with citation analysis is controversial (Bence \& Oppenheim, 2004), as is citation analysis itself (MacRoberts \& MacRoberts, 1996). Large-scale peer review exercises are particularly expensive and time consuming, however. The Italian national research assessment exercise (2001-2003), for instance, included "6661 experts (1465 from abroad), with a direct cost of 3.55 million Euros and a time length of 18 months" (Franceschet \& Costantini, 2011, p. 275). Books tend to be much longer than articles and so may need more time from assessors to evaluate in detail (Taylor \& Walker, 2009). In the 2008 UK Research Assessment Exercise (RAE), for instance, there were up to 100 books per RAE panel member in book-based fields (Kousha, Thelwall, \& Rezaie, 2011) and reading and evaluating these, which the panel members claim that they do, must present a considerable challenge.

An additional problem is that, in contrast to scientific impact, academic work may also aim for societal impacts as a primary or secondary goal, such as on industry, government or the general public. This may particularly apply in the arts and humanities where scholars use other informal scholarly channels in addition to formal publications to collect, share and disseminate information (Palmer, 2005). It may also apply to books more than to academic journals because the latter are typically targeted at researchers, although some may be in industry, whereas textbooks are widely used in education, and there are many examples of popular books written by academics about topics such as science (e.g., Oikkonen, 2013) and business (Bell \& Bodie, 2012). Popular books may differ from academic journal articles about the same topic by being more self-contained and easier to read (e.g., Myers, 1991). Nevertheless, it may be that more polemic books that are influential on society would naturally also draw attention in academia and so there is not always a dichotomy between popular and academic impact. An example is the bestseller Freakonomics, which was jointly written by an academic and a journalist in a popular style but had attracted 1215 Google Scholar citations in August 2014.

Alternative metrics to support peer review or citation analysis might help to ameliorate the above obstacles to book impact assessment. In recognition of this, there have been several 
initiatives to assess the impact of books with a spectrum of non-citation statistics such as publisher prestige (Donovan \& Butler, 2007; Giménez-Toledo \& Román, 2008; Torres-Salinas et al., 2012), library holdings (i.e., "libcitations") (Torres-Salinas \& Moed, 2009; White, Boell, Yu et al., 2009; Linmans, 2010; Zuccala \& Guns, 2013), library loan statistics (Cabezas-Clavijo et al., 2013), and social reference manager bookmarks (Hammarfelt, in press, 2014). This study contributes a new altmetric source, Amazon.com book reviews (number, stars and sentiments), and compares it with citation metrics (Thomson Reuters Book Citation Index and Google Books) and non-citation metrics (WorldCat.org and Mendeley) as well as Amazon.com sales ranks.

\section{Background}

Despite some pressures towards journal publishing, monographs in many parts of the social sciences and humanities seem to be maintaining their status as essential outputs for scholars (Engels, Ossenblok, \& Spruyt, 2012; Williams, Stevenson, Nicholas, et al., 2009). One study found that single author monographs in philosophy, sociology and economics attracted 7.7, 2.6, and 2.4 times more citations from journal articles than did equivalent journal articles, respectively (Lindholm-Romantschuk \& Warner, 1996; see also Nederhof \& van Raan, 1993). Even without including citations from books, this confirms that monographs make an important contribution to some disciplines. A large-scale investigation of cited references from Thomson ISI (now Thomson Reuters) indexed publications (1981-2000) showed that citations to journal articles (45\%) from social sciences and humanities (mainly) articles were almost half as common as in the natural sciences and engineering (86\%), with the remaining citations targeting nonserial literature, such as books and personal communications (Larivière, Archambault, Gingras, \& Vignola-Gagné, 2006). Nevertheless, conventional journal-based citation indexes are insufficient for the impact assessment of books in the social sciences and humanities because other monographs are a natural source of citations to monographs (e.g., Cronin, Snyder, \& Atkins, 1997; Glanzel \& Schoepflin, 1999; Huang \& Chang, 2008; Nederhof, 2006; Thompson, 2002).

The use of citations in research assessment is controversial because citations can be negative (Chubin \& Moitra, 1975), and can be used as part of a rhetorical strategy to support a text rather than as a way of acknowledging influences (MacRoberts \& MacRoberts, 1996). Moreover, some types articles can be valuable despite not being cited. For example, classificatory botanical and zoological articles are unlikely to be cited much but can be incorporated into recognised knowledge in through recognised reference works and databases instead (MacRoberts \& MacRoberts, 2010). Nevertheless, citation counts are not independent of research quality. They have been shown to correlate significantly in many cases, such as for Italian research 2000-2003 in 9 out of 10 disciplinary areas tested, with significant Spearman correlations between 0.42 and 0.81 (Franceschet \& Costantini, 2011), for field normalised citation counts and peer judgements for Norwegian natural science research groups at one university, with a Pearson correlation of 0.46 (Aksnes \& Taxt, 2004), for 56 Dutch condensed matter physics research programmes, with a Spearman correlation of 0.57 with field normalised citation counts for applied research and 0.63 for basic research (Rinia, van Leeuwen, van Vuren, \& van Raan, 1998), for 147 Dutch chemistry research groups (van Raan, 2006) and for several different subject areas in the UK (Norris \& Oppenheim, 2003; Oppenheim, 1995, 
1997). Nevertheless, these correlations are not universal, apply to articles rather than books, and are not strong enough to suggest that citation-based metrics should replace peer review although they may inform it (Warner, 2000).

\section{Citation impact assessment of books}

A number of different methods have been used to calculate citations to books.

Manual citation extraction from books: Citations can be manually extracted from books for smallscale bibliometric analyses (e.g., Cullars, 1998; Krampen, Becker, Wahner, \& Montada, 2007) but this is time-consuming and the results will be dependent on the number of books from which citations can be extracted.

Web of Science (WoS): WoS has previously been used for the impact assessment of monographs and edited books (e.g., Bar-llan, 2010; Butler \& Visser, 2006; Porta, Fernandez, \& Puigdomènech, 2006). Although WoS mainly indexes articles from academic journals and selected serials, its extensions include some books and conference proceedings and it extracts citations to other types of document, including books.

The Thomson Reuters Book Citation Index (BKCI): In 2011, Thomson Reuters created the $\mathrm{BKCl}$ to supplement its existing mainly journal-based WoS citation databases, beginning to remedy a limitation that was noticed nearly two decades ago (Garfield, 1996). Subscribers could add the $\mathrm{BKCl}$ to WoS so that their citation searches would cover a substantial amount of extra citations from books in addition to the original coverage of WoS. The initial $\mathrm{BKCl}$ indexed about 40,000 books and monographs starting from 2005. In early 2014 there were about 60,000 books: 40\% in the social sciences and $22 \%$ in the arts and humanities (The Book Citation Index, 2014). English-language books account for $97 \%$ of $\mathrm{BKCl}$-indexed books and most publishers (75\%) are from the UK and the USA, with low coverage of publishers in many countries with substantial social sciences and humanities research (Torres-Salinas et al., 2014). Hence BKCl currently has limited value for citation analysis. Moreover, citations to individual book chapters are not aggregated to whole edited volumes in $\mathrm{BKCl}$ and this could lead to underestimates of the citation counts of books (Leydesdorff \& Felt, 2012). In the social sciences and humanities, about $80 \%$ of citations to $\mathrm{BKCl}$ books and in the sciences about $92 \%$ of citations to $\mathrm{BKCl}$ books come from articles, in comparison to $16 \%$ and $5 \%$ from books, respectively (Kousha \& Thelwall, in press, 2014). Thus, $\mathrm{BKCl}$ does not yet seem to have substantial enough coverage of citations from books.

Scopus Book Search: Like WoS, Elsevier's Scopus citation database can also be used to locate citations to books from journal articles (e.g., Bar-Ilan, 2010; Kousha, Thelwall, \& Rezaie, 2011; Zuccala \& Guns, 2013). In mid-2013, Scopus introduced a new facility to search for citations from over 30,000 edited books and monographs, aiming to index about 75,000 books by the end of 2015. These books are from about 30 major publishers (e.g., Springer, Wiley-Blackwell, Elsevier and Princeton University Press) rather than being individually-selected books (Scopus content update: Books expansion project, 2014). Initial searches in Scopus suggested that over $99 \%$ of the indexed books are in English and so it probably has limitations similar to those of $\mathrm{BKCl}$.

Google Books (GB) citations: Although not containing a citation index, searches for bibliometric information within GB can identify citations from digitised books to academic publications 
(Kousha \& Thelwall, 2009). GB seems to give much better coverage of books than does any other source for citation impact assessment, especially in book-oriented disciplines (Kousha, Thelwall \& Rezaie, 2011). Nevertheless, GB searches retrieve many false matches and so each match needs to be individually checked. In response, an automatic method was developed and tested using the GB Applications Programming Interface (API) to automatically extract citations and remove false matches. Even with this filtering method, GB citations are more numerous than citations from $\mathrm{BKCl}$ in the humanities, with most $\mathrm{BKCl}$-enhanced results coming from WoS-indexed journal articles rather than books (Kousha \& Thelwall, in press 2014). The automatic GB citation searches give a high overall accuracy and coverage for citation results (over 90\%) although they may retrieve poor results for books with short titles and common author names if they generate too many false matches, making the filtering less effective (Kousha \& Thelwall, in press 2014).

\section{Non-bibliometric assessments of books}

There have been many previous investigations of different online sources as alternatives to citations for impact assessment in general, such as web links (Almind \& Ingwersen, 1997), web mentions (Cronin et al., 1998), download statistics (Bollen, Van De Sompel, Smith, \& Luce, 2005), online course syllabi (Kousha $\&$ Thelwall, 2008) and library holding counts (Torres-Salinas \& Moed, 2009). Positive correlations have been found between citation counts and altmetric indicators such as downloads counts (Brody, Harnad, \& Carr, 2006), tweets (Eysenbach, 2011), science blog citations (Shema, Bar-Ilan, \& Thelwall, 2013), readership bookmarks (Mohammadi \& Thelwall, 2014) and other social media tools (Costas, Zahedi, \& Wouters, 2014; Thelwall, Haustein, Larivière, \& Sugimoto, 2013; for a review see also Priem, 2014; Wouters \& Costas, 2012). Nevertheless, most altmetric investigations have been restricted to journal articles and so it is not clear whether the same would be true for edited books and monographs. However, some alternative metrics have been investigated for the impact assessment of books, including library holdings, publisher prestige and readership counts.

Libcitations: Academic librarians presumably tend to order books to support educational and research needs based on requests by teaching faculty members, researchers or students (see Association of College and Research Libraries, 2011). Academic library holding statistics may therefore reflect a combination of teaching and research impact, and this data is useful to assess the value of scholarly books (Calhoun, 2006; O'Neill, Connaway, \& Dickey, 2008; TorresSalinas \& Moed, 2008, 2009). The term "libcitation" has been coined for the number of libraries holding a book based on national or international union catalogues as an indication of its "cultural benefit" (White, Boell, Yu et al. 2009, p. 1087) and libcitations have been proposed to complement citations for the evaluation of humanities scholars (Linmans, 2010). The two measures have a low but significant positive correlation for history and literature (2001-2006) books ( 0.275 and 0.254 respectively), suggesting that they reflect weakly related but predominantly different types of impact.

Publisher prestige: In Flanders, academic books are labelled as subjected to peer review prior to publication or not (Verleysen \& Engels, 2013). Many evaluations need more discriminatory criteria, however, such as by restricting publications to "major academic presses or a few prestigious commercial publishers" (Donovan \& Butler, 2007, p. 237), or through "prestige 
weighted publication counts" (Donovan \& Butler, 2007, p. 241). Prestige can be gauged by surveys of academics or other stakeholders. Metz and Stemmer (1996), for instance, surveyed the collection development officers in many academic libraries, Garand and Giles (2011) surveyed 603 American political scientists and Giménez-Toledo, Tejada-Artigas and MañanaRodríguez (2013) surveyed 11,647 lecturers and Spanish researchers to obtain opinions about the quality of publishers in order to produce ranked lists. A quantitative alternative to reputational surveys might be 'Book Publishers Citation Reports' by analogy with the 'Journal Citation Reports' (Torres-Salinas et al., 2012), or perhaps a combination of citations and libcitations, although there are practical difficulties with data cleaning (Zuccala, Guns, Cornacchia, \& Bod, in press, 2014). The Scholarly Publishers Indicators (SPI) project has also attempted to rank scientific publishers in the social sciences and arts and humanities, using a survey of Spanish academics (see http://epuc.cchs.csic.es/SPI/).

Book reviews: Academic book reviews are significant scholarly outputs, especially in the humanities, and are regularly read and used to inform decision-making (e.g., Dilevko et al., 2006; Hartley, 2006; Spink, Robins, \& Schamber, 1998). Book reviews are also important for humanities research and library collection building and so the Association of College \& Research Libraries publishes Choice: Current Reviews for Academic Libraries, with over 7,000 reviews annually of academic books and digital resources (http://www.ala.org/acrl/choice/about). An early study found a high positive correlation $(r=0.620, p<0.01)$ between the number of reviews in the Book Review Index $(1,330)$ and the number of library holdings in the OCLC database (about 78,000) for 200 fiction titles (Shaw, 1991). A study of 420 sociology monographs found that books with positive reviews received significantly more Social SciSearch citations than did books with negative reviews (Nicolaisen, 2002). The extent to which books that are more reviewed also receive more citations seems to vary, with strong correlations in some fields (e.g., history) and no correlations in others (e.g., politics) (Gorraiz, Gumpenberger, \& Purnell 2014 - although they used Pearson correlations rather than Spearman). Book reviews themselves rarely receive citations, however, at least in history and literature, although the production of reviews is important in these fields and perhaps should be taken into account in research evaluations, alongside the quality of the reviewing journals (Zuccala \& van Leeuwen, 2011) or if the quality of the reviews themselves can be automatically assessed (Zuccala, van Someren, \& van Bellen 2014).

Reference manger bookmarks: Online reference manger (e.g., Mendeley) bookmarks positively correlate with citations to published journal articles (Bar-llan, 2012; Bar-llan et al. 2012; Li \& Thelwall, 2012; Li, Thelwall, \& Giustini, 2012; Mohammadi \& Thelwall, 2014; Thelwall, Haustein, Larivière, \& Sugimoto, 2013; Zahedi, Costas, \& Wouters, in press, 2014). These bookmarks have been commonly interpreted as 'readership counts' in the above studies, although bookmarking does not necessarily imply reading. A study of 54 English books published by Swedish universities during 2012 found that only 7\% were in Mendeley (Hammarfelt, in press, 2014), suggesting that bookmarks may not be common enough to be valuable for book impact assessment, although a larger sample is needed to check this.

\section{Amazon.com book reviews}

In May 2014, Amazon.com was the $12^{\text {th }}$ most popular website globally and $5^{\text {th }}$ in the United States (http://www.alexa.com/siteinfo/amazon.com). Since anyone can write book reviews on 
the site and vote or add comments on other reviews, Amazon has become a large repository of consumer book review information. These reviews seem to affect or reflect sales (Wu \& Zheng, 2012) and tend to be positive, with the apparent impact of 1-star reviews being apparently greater than that of 5-star reviews (Chevalier \& Mayzlin, 2006). In general, negative reviews seem to be more helpful than positive reviews (Wu, Van Der Heijden, \& Korfiatis, 2011), as are those with extreme ratings ( 1 and 5 ) (Forman, Ghose, \& Wiesenfeld, 2008). Book reviews that are voted as being helpful or that are more detailed seem to have a stronger relationship with sales (Chen, Dhanasobhon, \& Smith, 2008). This relationship is also stronger if book reviews contain information about the reviewers' identities (Forman, Ghose, \& Wiesenfeld, 2008). Book review writing and reading in online bookshops are complex behaviours, however (Leino \& Räihä, 2007; Shen, Yu, \& Rees, 2009). For example, an individual review may be part of a reviewer's overall strategy for gaining attention or reputation (Shen, Yu, \& Rees, 2009).

\section{Research questions}

This study assesses whether online book reviews from Amazon.com could be useful for the impact assessment of academic books. To address this goal, the overall research design is to compare metrics derived from Amazon.com reviews with formal citations and Altmetric indicators for academic monographs and best-selling textbooks. The following research questions drive the investigation, in the belief that testing for correlations between metrics is a logical first step for evaluating the potential contribution of new metrics (Sud \& Thelwall, 2014; see also: Oppenheim, 2000), and supported by the correlation between citation counts and peer review scores in many cases discussed above. The main evaluation is for a collection of (presumably) high quality monographs but the secondary evaluation (question 2) covers bestselling books and so may identify those that have reached non-academic audiences even if they may not be recognised as high quality scholarly manuscripts in the traditional sense.

1. Do Amazon metrics correlate with citation counts, library holdings and reader counts for scientific monographs?

2. Do Amazon metrics correlate with citation counts for best-selling textbooks in Amazon?

3. Are there disciplinary differences in the answers to the above questions?

\section{Methods}

The primary set of books to be assessed was taken from $\mathrm{BKCl}$ because this is a large collection of academic books from reputable publishers. This choice means that the results will reveal little about non-English monographs, but, given the origins of Amazon in the USA, it seems reasonable to pick an English-centred sample for a first evaluation of Amazon reviews for academia.

\section{Research Population}

BKCl-indexed single edition monographs: A list of all BKCl books from 2008 was first extracted. The year 2008 provides books sufficient time (at least five years) to receive citations, readership bookmarks, library holdings, reviews and sale ranks from the selected sources (see below). Edited books (i.e., those with an entry in the BKCI BE (Book Editor) field), books with different editions (e.g., Surfactant Science and Technology, 3rd Edition), volume series (e.g., Advances in 
Molecular Toxicology, Vol. 2) and annual reviews (e.g., Annual Review of Biochemistry) were excluded to restrict the dataset to monographs because citations to book chapters and edited volumes are not aggregated to whole books in $\mathrm{BKCl}$. Books with single word titles (e.g., 'Spinoza' by Michael Della Rocca) were also excluded (15; $0.5 \%)$ to reduce the problem of false matches (see below), leaving a total of 2,739 monographs (about $45 \%$ of all book types in $\mathrm{BKCl}$ in 2008). The different $\mathrm{BKCl}$ subjects were merged into three broad areas (science, social science, and arts and humanities) in order to give large enough datasets for powerful statistical tests.

Amazon best-selling textbooks: Books from the US version of Amazon 'Best Sellers in Textbooks' lists in five science, five social science and five arts and humanities categories, as classified by Amazon, were extracted to cover a range of different subject areas. This seems to be the only practical method to identify lists of best-selling academic books from specific subject areas from Amazon and seems to reflect recent sales rather than total sales. The initial collection included 1,500 textbooks from the top 100 best-selling textbooks in 15 fields on April 30th, 2014 (http://www.amazon.com/Best-Sellers-Books-Textbooks/zgbs/books/465600). All book formats, such as paperback, hardback and spiral-bound, were included but 182 duplicate titles within subject categories were excluded as well as 13 audio CDs, pamphlets and cards, leaving 1,305 unique textbooks. This dataset is limited because it is based upon recent sales and an unknown categorisation method and includes books from different years, in different formats and with multiple editions. Nevertheless, it may serve to give insights into the relationship between citations and numbers of reviews for the most popular academic books.

\section{$B K C l$ and $G B$ Citations}

For $\mathrm{BKCl}$ citations, WoS citation counts were used (the $T C$ field), including book citations from $\mathrm{BKCl}$ as well citations from journal and conference proceedings within Web of Science citation indexes. For GB citations, Google Books API searches were used in the previously developed and tested software, Webometric Analyst (http://lexiurl.wlv.ac.uk, "Books" tab), to locate GB citations and to remove false matches (e.g., advertisements, book reviews and bibliographies) for all 2,739 $\mathrm{BKCl}$ monographs (for method details see: Kousha \& Thelwall, 2014). As shown below, a typical query to locate GB citations included the last name of the first author, a phrase search for the first seven words from the book title, and its publication year.

\section{Mardock "Our Scene is London: Ben Jonson's City" 2008}

Publisher names were added to the queries for monographs with less than four words in their titles to reduce the number of false matches. This is reasonable because publisher names are almost always included in book citations, although they are sometimes abbreviated or written in different forms.

\section{Batey "Brand Meaning" Routledge 2008}

For the set of 1,305 Amazon best-selling textbooks, GB searches were conducted with the last name of the first author, a phrase search for the first seven words from the book title and the 
publisher name. The publication year was not included so that the results could include multiple editions of each book, if there were any.

\section{Holt "Why Does the World Exist?: An Existential" "Liveright"}

\section{Amazon Metrics}

Review counts, review ratings and sales ranks: The main Amazon URLs of the 2,739 $\mathrm{BKCl}-$ indexed monographs (e.g., http://www.amazon.com/The-Shifting-Grounds-RaceMultiethnic/dp/0691146187) were identified with automatic Bing searches in Webometric Analyst. Each query included the last name of the first author, the book title and two terms (ISBN-10: and ISBN-13:) as well as the Bing command site:www.amazon.com to restrict the results to book pages in Amazon.com (see the example below). For about 60 records not found by this method, ad-hoc manual searches were used instead.

Fisman "Economic Gangsters Corruption Violence and the Poverty" ISBN-10: ISBN-13:

site:www.amazon.com

The Amazon book webpages were downloaded from their URLs using Webometric Analyst again. The number of customer reviews, the average ratings of the reviews (e.g., 4.7 out of 5 stars) and the Amazon best sellers rank (presumably reflecting recent sales rather than total sales) were then extracted from each page by Webometric Analyst ( "Books" tab). The same strategy was used for the 1,305 Amazon best-selling textbooks.

Review sentiment: To estimate the strength of positive and negative sentiment in the (up to) 10 'most helpful' Amazon.com book reviews per book, the automatic sentiment analysis software SentiStrength (http://sentistrength.wlv.ac.uk/) was used, which is designed for short and medium-sized informal social web texts. The most helpful reviews were selected because book reviews with many helpful votes have a stronger influence on the consumer and may include both negative or positive comments (Chen, Dhanasobhon, \& Smith, 2008; Forman, Ghose, \& Wiesenfeld, 2008). There were only 40 (1.5\%) titles with more than 10 Amazon.com reviews for the 2,739 $\mathrm{BKCl}$-indexed monographs in the dataset and so almost all of the relevant book reviews were processed. The SentiStrength software reports positive or negative sentiment strength based on a dual scale of 1 (no positive sentiment) to 5 (strong positive sentiment), and 1 (no negative sentiment) to -5 (strong negative sentiment) (Thelwall, Buckley, \& Paltoglou, 2012; Thelwall, Buckley, Paltoglou, et al., 2010). Although some other sentiment analysis programs are more specifically designed for the analysis of review texts (Pang \& Lee, 2008), a more general sentiment analysis program like SentiStrength is desirable because the objective is to extract sentiments about the content of the books rather than an overall evaluation of whether to buy them or not.

\section{Mendeley bookmarks}

The Mendeley API in Webometric Analyst (see its "Mendeley" tab), was used to search for Mendeley bookmark counts for the 2,739 BKCl-indexed monographs and the 1,305 Amazon best-selling textbooks. The query was based on the last name of the first author, the title of the 
publication and the publication year for $\mathrm{BKCl}$-indexed monographs, and the last name of the first author and the title of the book for the Amazon best-selling books.

\section{WorldCat library holdings}

WorldCat (http://www.worldcat.org) is the world's largest library holding catalogue with more than 2 billion items from over 72,000 libraries in 170 countries (http://oclc.org/worldcat/catalog.en.html). The ISBNs of the 2,739 BKCl-indexed monographs were manually searched for in the WorldCat (http://www.worldcat.org) main search interface, recording the number of library holdings. ISBNs recorded in $\mathrm{BKCl}$ were used to avoid recording library holdings for different editions or for different book formats. However, in rare cases the ISBN searches were unsuccessful and further ad-hoc searches were conducted with bibliographic information to find the missing publications.

\section{Results}

\section{BKCl monographs from 2008}

The median number of Amazon reviews for $\mathrm{BKCl}$ monographs from 2008 in the dataset is zero in all subject areas (Table 1). Moreover, $71 \%$ did not have a review, $27.5 \%$ received $1-10$ reviews and only $1.5 \%$ had more than 10 reviews. Assuming that $\mathrm{BKCl}$ prioritises "books and book series that have relatively greater citation impact" (Testa, 2011, p. 3), this relatively low number suggests that good quality academic textbooks often fail to get any Amazon reviews. Nevertheless, the higher percentage of monographs that have at least one Amazon book review (29\%) than have at least one Mendeley bookmark (7\%) suggests that Amazon reviews may still be common enough to be used for some types of wider impact assessment, although libcitations have a clear numerical advantage.

Table 1. BKCl, GB citations, Amazon reviews, WorldCat library holdings and Mendeley reader counts for $\mathrm{BKCl}$ monographs published in 2008 in three broad fields.

\begin{tabular}{|c|c|c|c|c|c|c|}
\hline Fields & $\begin{array}{l}\text { Mono- } \\
\text { graphs }\end{array}$ & $\begin{array}{l}\text { BKCl } \\
\text { No. (\% with } \\
\text { cites*) } \\
\text { median } \\
\text { (mean) } \\
\text { SD } \\
\end{array}$ & $\begin{array}{l}\text { GB } \\
\text { No. (\% with } \\
\text { cites*) } \\
\text { median } \\
\text { (mean) } \\
\text { SD } \\
\end{array}$ & $\begin{array}{l}\text { Amazon rev. } \\
\text { No. (\% with } \\
\text { reviews*) } \\
\text { median (mean) } \\
\text { SD }\end{array}$ & $\begin{array}{l}\text { WorldCat } \\
\text { No. (\% with } \\
\text { holdings*) } \\
\text { median } \\
\text { (mean) } \\
\text { SD } \\
\end{array}$ & $\begin{array}{l}\text { Mendeley } \\
\text { No. (\% with } \\
\text { bookmarks*) } \\
\text { median } \\
\text { (mean) } \\
\text { SD }\end{array}$ \\
\hline $\begin{array}{l}\text { Arts and } \\
\text { human- } \\
\text { ities }\end{array}$ & 1,262 & $\begin{array}{l}12,224(81 \%) \\
5(9.7) 15.9\end{array}$ & $\begin{array}{l}11,720(92 \%) \\
6(9.3) \\
8.5\end{array}$ & $\begin{array}{l}1,396(31 \%) \\
0(1.1) \\
4.5\end{array}$ & $\begin{array}{l}482,081(100 \%) \\
303(382) \\
251.6\end{array}$ & $\begin{array}{l}832(4 \%) \\
0(0.7) \\
5.2\end{array}$ \\
\hline $\begin{array}{l}\text { Social } \\
\text { sciences }\end{array}$ & 759 & $\begin{array}{l}7,839(80 \%) \\
4(10.3) \\
19.3\end{array}$ & $\begin{array}{c}5,270(85 \%) \\
4(6.9) 7.6\end{array}$ & $\begin{array}{l}635(25 \%) \\
0(0.8) \\
2.7\end{array}$ & $\begin{array}{l}226,653(100 \%) \\
242(298.6) \\
202.6\end{array}$ & $\begin{array}{l}772(6 \%) \\
0(1) \\
9.7\end{array}$ \\
\hline $\begin{array}{l}\text { Science } \\
\text { and } \\
\text { medicine }\end{array}$ & 718 & $\begin{array}{l}7,635(46 \%) \\
0(10.6) 30.5\end{array}$ & $\begin{array}{l}2,871(70 \%) \\
2(4) \\
5.4\end{array}$ & $\begin{array}{l}533(29 \%) \\
0(0.7) \\
2.2\end{array}$ & $\begin{array}{l}227,639(100 \%) \\
293.5(317) \\
186.5\end{array}$ & $\begin{array}{l}2,387(14 \%) \\
0(3.3) \\
16.5\end{array}$ \\
\hline & 2,739 & $\begin{array}{l}27,698(72 \%) \\
3(10.1)\end{array}$ & $\begin{array}{l}19,861(84 \%) \\
5(7.3)\end{array}$ & $\begin{array}{l}2,564(29 \%) \\
0(0.9)\end{array}$ & $\begin{array}{c}936,373(100 \%) \\
286(341.9)\end{array}$ & $\begin{array}{l}3,991(7 \%) \\
0(1.5)\end{array}$ \\
\hline
\end{tabular}




\begin{tabular}{|l|l|l|l|l|l|l|}
\hline Total & $\mathbf{2 1 . 5}$ & $\mathbf{7 . 8}$ & 3.5 & 226 & 10.5 \\
\hline
\end{tabular}

$* \%$ of monographs with at least one result in BKCI, GB, WorldCat, Mendeley or Amazon

Spearman correlation tests were used to assess the extent of the agreement between various indicators and Amazon metrics (tables 2 to 4). There are significant positive correlations $(p<0.01)$, albeit weak, between Amazon metrics and both citation metrics ( $\mathrm{BKCl}$ and $\mathrm{GB})$ and libcitations. Thus, in general, monographs with more citations or library holdings tend to receive more online reviews, higher star-based ratings, better sales rankings and more positive sentiment in reviews.

In terms of disciplinary differences, correlations between $\mathrm{BKCl}$ citations and the number of Amazon reviews are higher in the social sciences (0.223) and arts and humanities (0.189) than in science and medicine (0.121). The highest correlations between WorldCat library holdings and Amazon reviews are in arts and humanities (0.348) and social sciences (0.321), but the correlation is low in sciences and medicine (0.129). Hence, it seems that books with more reviews tend to be more often acquired by libraries and vice versa, particularly outside of science and medicine. Only in science and medicine are there significant correlations between Mendeley bookmarks and Amazon metrics (excluding Amazon sales), although they are very low.

Star ratings and review sentiments are only available for the minority of monographs that have received at least one Amazon review, which limits their value. Nevertheless, there are also significant positive and negative correlations between citation indicators and positive and negative review sentiments, respectively, in all fields, indicating that books with higher citation impact receive more positive reviews and fewer negative reviews. WorldCat library holdings correlate $(p<0.01)$ with the sentiments of reviews at a level that is even higher than with citation indicators, ranging from 0.306 to 0.319 , but the correlation is negative and much lower in science and medicine (-.116). It is strange that the sentiments expressed in the reviews do not correlate significantly with their star ratings even though both sentiments and star ratings correlate significantly with citation metrics. The reason might be that academic reviews try to be balanced to some extent and hence a highly cited book that the review author does not like could be praised for its contribution but criticised for the aspect that the author does not like. Nevertheless, this suggests that the review contents might relate to different aspect of the monographs (e.g., the accuracy of the book contents) than do the review star ratings (e.g., whether the book is worth buying).

Table 2 Spearman correlations between $\mathrm{BKCl}$ and GB citations with WorldCat library holdings, online syllabus mentions, Amazon metrics and Mendeley readers for social science $\mathrm{BKCl}$ monographs published in 2008 ( $n=759$ except where noted).

\begin{tabular}{|l|l|l|l|l|l|l|l|l|l|l|}
\hline Evidence & Metrics & $\mathrm{BKCl}$ & $\mathrm{GB}$ & WorldCat & Mendeley & $\begin{array}{l}\text { Amazon } \\
\text { reviews }\end{array}$ & $\begin{array}{l}\text { Amazon } \\
\text { stars }+\end{array}$ & $\begin{array}{l}\text { Amazon } \\
\text { sales } \\
\text { rank }\end{array}$ & $\begin{array}{l}\text { Sentim. } \\
\text { pos+ }\end{array}$ & $\begin{array}{l}\text { Sentim. } \\
\text { neg+ }\end{array}$ \\
\hline $\begin{array}{l}\text { Citation } \\
\text { metrics }\end{array}$ & $\mathrm{BKCl}$ & 1 & $.490^{* *}$ & $.145^{* *}$ & .053 & $.223^{* *}$ & $.219^{* *}$ & $-.230^{* *}$ & $.216^{* *}$ & $-218^{* *}$ \\
\cline { 2 - 11 } & & 1 & $.234^{* *}$ & .017 & $.182^{* *}$ & $.165^{* *}$ & $-.243^{* *}$ & $.164^{* *}$ & $-.166^{* *}$ \\
\hline
\end{tabular}




\begin{tabular}{|c|c|c|c|c|c|c|c|c|}
\hline \multirow{2}{*}{$\begin{array}{l}\text { Non- } \\
\text { citation } \\
\text { metrics }\end{array}$} & WorldCat & 1 & $.072^{*}$ & $.321^{* *}$ & $.285^{* *}$ & $-.292 * *$ & $.309 * *$ & $-.306^{* *}$ \\
\hline & Mendeley & & 1 & .062 & .047 & -.096 & .068 & -.054 \\
\hline \multirow{5}{*}{$\begin{array}{l}\text { Amazon } \\
\text { metrics }\end{array}$} & $\begin{array}{l}\text { Amazon } \\
\text { reviews }\end{array}$ & & & 1 & $-.251^{* *}$ & $-.353^{* *}$ & .011 & .006 \\
\hline & $\begin{array}{l}\text { Amazon } \\
\text { stars+ }\end{array}$ & & & & 1 & $-.327^{* *}$ & -.058 & .120 \\
\hline & $\begin{array}{l}\text { Amazon } \\
\text { sales rank }\end{array}$ & & & & & 1 & $-.327^{* *}$ & $.325^{* *}$ \\
\hline & $\begin{array}{l}\text { Sentim. } \\
\text { post }\end{array}$ & & & & & & 1 & $-.293 * *$ \\
\hline & $\begin{array}{l}\text { Sentim. } \\
\text { neg+ }\end{array}$ & & & & & & & 1 \\
\hline
\end{tabular}

**. Significant at $p=0.01$

*. Significant at $\mathrm{p}=0.05$

+ Books with 0 reviews were excluded from correlations with this data $(n=190)$

Table 3 Spearman correlations between $\mathrm{BKCl}$ and GB citations with WorldCat library holdings, online syllabus mentions, Amazon metrics and Mendeley readers for $\mathrm{BKCl}$ arts and humanities monographs published in 2008 ( $n=1,262$ except where noted).

\begin{tabular}{|c|c|c|c|c|c|c|c|c|c|c|}
\hline Evidence & Metrics & $\begin{array}{l}\mathrm{BK} \\
\mathrm{Cl}\end{array}$ & GB & WorldCat & Mendeley & $\begin{array}{l}\text { Amazon } \\
\text { reviews }\end{array}$ & $\begin{array}{l}\text { Amazon } \\
\text { stars+ }\end{array}$ & $\begin{array}{l}\text { Amazon } \\
\text { sales } \\
\text { rank }\end{array}$ & $\begin{array}{l}\text { Sentim. } \\
\text { pos+ }\end{array}$ & $\begin{array}{l}\text { Sentim. } \\
\text { neg+ }\end{array}$ \\
\hline \multirow{2}{*}{$\begin{array}{l}\text { Citation } \\
\text { metrics }\end{array}$} & $\mathrm{BKCl}$ & 1 & $.576^{* *}$ & $.141 * *$ & .049 & $.189^{* *}$ & $.170^{* *}$ & $-.252^{* *}$ & $.174 * *$ & $-.181 * *$ \\
\hline & GB & & 1 & $.268 * *$ & .003 & $.188^{* *}$ & $.156^{* *}$ & $-.254 * *$ & $.168^{* *}$ & $-.182 * *$ \\
\hline \multirow{2}{*}{$\begin{array}{l}\text { Non- } \\
\text { citation } \\
\text { metrics } \\
\end{array}$} & WorldCat & & & 1 & .024 & $.348^{* *}$ & $.304^{* *}$ & $-.191 * *$ & $.312 * *$ & $-.319 * *$ \\
\hline & Mendeley & & & & 1 & .003 & .004 & -.033 & .010 & 016 \\
\hline \multirow{5}{*}{$\begin{array}{l}\text { Amazon } \\
\text { metrics }\end{array}$} & $\begin{array}{l}\text { Amazon } \\
\text { reviews }\end{array}$ & & & & & 1 & $-.229 * *$ & $-.321^{* *}$ & .070 & -.076 \\
\hline & $\begin{array}{l}\text { Amazon } \\
\text { stars+ }\end{array}$ & & & & & & 1 & $-.301 * *$ & .006 & $.202 * *$ \\
\hline & $\begin{array}{l}\text { Amazon } \\
\text { sales rank }\end{array}$ & & & & & & & 1 & $-.288^{* *}$ & $.287 * *$ \\
\hline & $\begin{array}{l}\text { Sentim. } \\
\text { post }\end{array}$ & & & & & & & & 1 & $-.165^{* *}$ \\
\hline & $\begin{array}{l}\text { Sentim. } \\
\text { neg+ }\end{array}$ & & & & & & & & & 1 \\
\hline
\end{tabular}

**. Significant at $\mathrm{p}=0.01$

+ Books with 0 reviews were excluded from correlations with this data $(n=391)$

Table 4 Spearman correlations between $\mathrm{BKCl}$ and GB citations with WorldCat library holdings, online syllabus mentions, Amazon metrics and Mendeley readers for science, engineering and medicine $\mathrm{BKCl}$ monographs published in 2008 ( $n=718$ except where noted).

\begin{tabular}{|l|l|l|l|l|l|l|l|l|l|l|}
\hline Evidence & Metrics & $\mathrm{BKCl}$ & $\mathrm{GB}$ & WorldCat & Mendeley & $\begin{array}{l}\text { Amazon } \\
\text { reviews }\end{array}$ & $\begin{array}{l}\text { Amazon } \\
\text { stars+ }\end{array}$ & $\begin{array}{l}\text { Amazon } \\
\text { sales } \\
\text { rank }\end{array}$ & $\begin{array}{l}\text { Sentim. } \\
\text { pos+ }\end{array}$ & $\begin{array}{l}\text { Sentim. } \\
\text { neg+ }\end{array}$ \\
\hline
\end{tabular}




\begin{tabular}{|c|c|c|c|c|c|c|c|c|c|c|}
\hline \multirow{2}{*}{$\begin{array}{l}\text { Citation } \\
\text { metrics }\end{array}$} & $\mathrm{BKCl}$ & 1 & $.185^{* *}$ & .088 & $.106 * *$ & $.121^{* *}$ & $.120^{* *}$ & $-.128 * *$ & $.108^{* *}$ & $-.100 * *$ \\
\hline & GB & & 1 & $.112 * *$ & $.139 * *$ & $.158^{* *}$ & $.153^{* *}$ & $-.098^{* *}$ & $.142 * *$ & $-.150 * *$ \\
\hline \multirow{2}{*}{$\begin{array}{l}\text { Non- } \\
\text { citation } \\
\text { metrics }\end{array}$} & WorldCat & & & 1 & .051 & $.129 * *$ & $.105^{* *}$ & -.039 & $.097 * *$ & $-.116^{* *}$ \\
\hline & Mendeley & & & & 1 & $.101^{* *}$ & $.106 * *$ & -.041 & $.098 * *$ & $-.097 * *$ \\
\hline \multirow{5}{*}{$\begin{array}{l}\text { Amazon } \\
\text { metrics }\end{array}$} & $\begin{array}{l}\text { Amazon } \\
\text { reviews }\end{array}$ & & & & & 1 & -.095 & $-.389 * *$ & .031 & $-.136^{*}$ \\
\hline & $\begin{array}{l}\text { Amazon } \\
\text { stars+ }\end{array}$ & & & & & & 1 & $-.362^{* *}$ & .134 & $.319 * *$ \\
\hline & $\begin{array}{l}\text { Amazon } \\
\text { sales rank }\end{array}$ & & & & & & & 1 & $-.364^{* *}$ & $.358 * *$ \\
\hline & $\begin{array}{l}\text { Sentim. } \\
\text { post }\end{array}$ & & & & & & & & 1 & -.042 \\
\hline & $\begin{array}{l}\text { Sentim. } \\
\text { neg+ }\end{array}$ & & & & & & & & & 1 \\
\hline
\end{tabular}

**. Significant at $\mathrm{p}=0.01$

+ Books with 0 reviews were excluded from correlations with this data $(n=208)$

\section{Amazon best-selling textbooks}

There are considerably more Amazon book reviews (total: 82,498; median: 19) than there are GB citations (total: 30,086; median: 7) and Mendeley bookmarks (total: 34,663; median: 0) for the 1,305 Amazon best-selling textbooks (Table 5). Of these, about $96 \%$ had at least one review and $72 \%$ had at least one GB citation. Although only $16 \%$ of the Amazon best-selling textbooks had been bookmarked in Mendeley, this is more than twice as high as for the $\mathrm{BKCl}$-indexed scientific books (about 7\%). There is a huge difference between the median number of Amazon reviews for $\mathrm{BKCl}$ academic books (see Table 1 ) and the best-selling textbooks (0 vs. 19 respectively), whereas the median of $\mathrm{GB}$ citations are similar for $\mathrm{BKCl}$ and best-selling textbooks ( 7 vs. 5 respectively). The results suggest that scientific books with greater citation impact indexed by $\mathrm{BKCl}$ could be less reviewed by the online community, but that best-selling textbooks rarely remain uncited. Note that the median is a better measure of central tendency than the mean because in most cases the distributions were highly skewed.

Table 5 also shows that there are disciplinary differences between Amazon reviews and GB citations. In literature, biology \& life sciences, and medicine the Amazon book review medians (123.5, 54 and 44, respectively) are much higher than for GB citations(16.5, 0 and 2, respectively). The importance of book reviews in literature (Zuccala \& van Leeuwen, in press, 2014) could explain the largest of the differences. Nevertheless, in anthropology and political science the GB citation medians (both 27) are more than twice as much as the Amazon book review medians (12 and 11 respectively), suggesting that best-selling textbooks can receive many formal citations from other books.

As shown in Table 5, there are low but statistically significant Spearman correlations between the number of Amazon reviews and GB citation counts (0.171) for the best-selling textbooks overall, although the correlations were insignificant for seven subject areas. The correlations between Amazon review counts and GB citation counts are higher for astronomy and astrophysics (0.581), literature (0.516) and sociology (0.348) textbooks than for the other seven fields. Hence, it seems that the higher numbers of GB citations were also reflected in online book reviews and vice versa, suggesting that in some subject areas Amazon book review counts and formal citation counts reflect similar types of intellectual impact. In contrast, the 
low citations may be caused by some of the currently best-selling books in a field being too new to attract many citations yet. There are low to medium significant correlations between GB citations and Mendeley bookmarks for all 15 disciplines (Table 5), although few textbooks had been bookmarked in Mendeley (17\%), which undermines the usefulness of this correlation. There are significant correlations between Amazon reviews and Mendeley bookmarks in only three subject areas (Table 5). The same subject areas have the highest correlations between Amazon review and GB citations.

Table 5. Descriptive statistics and Spearman correlations between Amazon reviews, Google Books citations and Mendeley bookmarks for best-selling books across science, social science and arts and humanities.

\begin{tabular}{|c|c|c|c|c|c|c|c|}
\hline \multirow[b]{2}{*}{ Fields } & \multicolumn{4}{|c|}{ Descriptive statistics } & \multicolumn{3}{|c|}{ Spearman correlations } \\
\hline & $\begin{array}{l}\text { Amazon } \\
\text { best- } \\
\text { selling } \\
\text { textbooks }\end{array}$ & $\begin{array}{l}\text { Amazon rev. } \\
\text { No. (\% with } \\
\text { cites*) } \\
\text { median } \\
\text { (mean) } \\
\text { Max }\end{array}$ & $\begin{array}{l}\text { GB } \\
\text { No. (\% with } \\
\text { cites*) } \\
\text { median } \\
\text { (mean) } \\
\text { Max } \\
\end{array}$ & $\begin{array}{l}\text { Mendeley } \\
\text { No. (\% with } \\
\text { bookmarks*) } \\
\text { median } \\
\text { (mean) } \\
\text { Max }\end{array}$ & $\begin{array}{l}\text { Amazon } \\
\text { rev. } \\
\text { and GB }\end{array}$ & $\begin{array}{l}\text { Mendeley } \\
\text { and GB }\end{array}$ & $\begin{array}{l}\text { Amazon rev. } \\
\text { and } \\
\text { Mendeley }\end{array}$ \\
\hline Anthropology & 82 & $\begin{array}{l}3889(94 \%) \\
12(47.4) \\
M a x=1631\end{array}$ & $\begin{array}{l}2154(90 \%) \\
27(26.3) \\
M a x=93\end{array}$ & $\begin{array}{l}3948(21 \%) \\
0(48.1) \\
M a x=1347\end{array}$ & 0.15 & $.431 * *$ & 0.091 \\
\hline $\begin{array}{l}\text { Commun. \& } \\
\text { journalism }\end{array}$ & 89 & $\begin{array}{l}2634(99 \%) \\
16(29.6) \\
M a x=137\end{array}$ & $\begin{array}{l}1719(71 \%) \\
5(19.31) \\
\operatorname{Max}=216 \\
\end{array}$ & $\begin{array}{l}2152(12 \%) \\
0(24.2) \\
\operatorname{Max}=814\end{array}$ & $.262 *$ & $.348 * *$ & $.227^{*}$ \\
\hline $\begin{array}{l}\text { Political } \\
\text { science }\end{array}$ & 91 & $\begin{array}{l}4454(92 \%) \\
11(48.9) \\
M a x=842\end{array}$ & $\begin{array}{l}3007(91 \%) \\
27(33) \\
M a x=178\end{array}$ & $\begin{array}{l}2744(21 \%) \\
0(30.1) \\
M a x=373\end{array}$ & $.286 * *$ & $.400 * *$ & 0.145 \\
\hline Psychology & 88 & $\begin{array}{l}3321(100 \%) \\
12.5(37.7) \\
\operatorname{Max}=1255 \\
\end{array}$ & $\begin{array}{l}2157(84 \%) \\
15(24.5) \\
M a x=188 \\
\end{array}$ & $\begin{array}{l}3586(33 \%) \\
0(40.7) \\
M a x=1126 \\
\end{array}$ & $.259 *$ & $.362 * *$ & -0.063 \\
\hline Sociology & 79 & $\begin{array}{l}2641(97 \%) \\
19(33.4) \\
\operatorname{Max}=307 \\
\end{array}$ & $\begin{array}{l}2248(85 \%) \\
19(28.5) \\
\operatorname{Max}=233 \\
\end{array}$ & $\begin{array}{l}1610(28 \%) \\
0(20.4) \\
\operatorname{Max}=526 \\
\end{array}$ & $.348 * *$ & $.228 *$ & $.249 *$ \\
\hline Architecture & 92 & $\begin{array}{l}2026(93 \%) \\
16(22) \\
M a x=138\end{array}$ & $\begin{array}{l}1600(70 \%) \\
4(17.4) \\
M a x=175 \\
\end{array}$ & $\begin{array}{l}994(10 \%) \\
0(10.8) \\
M a x=504 \\
\end{array}$ & $.239 *$ & $.360 * *$ & 0.127 \\
\hline Linguistics & 85 & $\begin{array}{l}2138(93 \%) \\
14(25.2) \\
\operatorname{Max}=158 \\
\end{array}$ & $\begin{array}{l}1847(75 \%) \\
7(21.7) \\
M a x=266 \\
\end{array}$ & $\begin{array}{l}1876(15 \%) \\
0(22.1) \\
\operatorname{Max}=623 \\
\end{array}$ & 0.057 & $.349 * *$ & 0.065 \\
\hline Literature & 80 & $\begin{array}{l}24850(100 \%) \\
123.5(310.6) \\
\operatorname{Max}=4305\end{array}$ & $\begin{array}{l}2571(83 \%) \\
16.5(32.1) \\
M a x=209\end{array}$ & $\begin{array}{l}1092(16 \%) \\
0(13.6) \\
M a x=182\end{array}$ & $.516 * *$ & $.201 *$ & $.304 * *$ \\
\hline $\begin{array}{l}\text { Performing } \\
\text { arts }\end{array}$ & 88 & $\begin{array}{l}3139(97 \%) \\
27.5(35.7) \\
\text { Max=239 }\end{array}$ & $\begin{array}{l}879(63 \%) \\
2(10) \\
\text { Max=116 }\end{array}$ & $\begin{array}{l}241(5 \%) \\
0(2.7) \\
M a x=162 \\
\end{array}$ & -0.018 & $.254 *$ & -0.045 \\
\hline
\end{tabular}




\begin{tabular}{|c|c|c|c|c|c|c|c|}
\hline Philosophy & 81 & $\begin{array}{l}6697(98 \%) \\
27(82.7) \\
M a x=2331 \\
\end{array}$ & $\begin{array}{l}4917(79 \%) \\
34(60.7) \\
\operatorname{Max}=217 \\
\end{array}$ & $\begin{array}{l}170(36 \%) \\
0(63.8) \\
M a x=2406 \\
\end{array}$ & 0.218 & $.383 * *$ & 0.026 \\
\hline $\begin{array}{l}\text { Astronomy \& } \\
\text { astrophysics }\end{array}$ & 91 & $\begin{array}{l}3720(92 \%) \\
16(40.9) \\
M a x=592\end{array}$ & $\begin{array}{l}1728(70 \%) \\
4(19) \\
M a x=220\end{array}$ & $\begin{array}{l}278(12 \%) \\
0(3) \mathrm{Max}=76\end{array}$ & $.581 * *$ & $.406 * *$ & $.304 * *$ \\
\hline $\begin{array}{l}\text { Biology \& life } \\
\text { sciences }\end{array}$ & 91 & $\begin{array}{l}9876(98 \%) \\
54(108.5) \\
\operatorname{Max}=490\end{array}$ & $\begin{array}{l}\text { 1052(43\%) } \\
0(11.6) \\
\operatorname{Max}=164\end{array}$ & $\begin{array}{l}1372(10 \%) \\
0(14.9) \\
M a x=922\end{array}$ & 0.174 & $.395^{* *}$ & -0.022 \\
\hline Engineering & 92 & $\begin{array}{l}2930(99 \%) \\
18.5(31.8) \\
M a x=189\end{array}$ & $\begin{array}{l}1515(57 \%) \\
1(16.5) \\
\operatorname{Max}=170\end{array}$ & $\begin{array}{l}7738(11 \%) \\
0(84.1) \\
\text { Max=7509 }\end{array}$ & 0.021 & $.356 * *$ & -0.03 \\
\hline $\begin{array}{l}\text { Environment } \\
\text { al science }\end{array}$ & 93 & $\begin{array}{l}1928(88 \%) \\
8(20.7) \\
\operatorname{Max}=131\end{array}$ & $\begin{array}{l}1439(69 \%) \\
5(15.5) \\
\operatorname{Max}=148 \\
\end{array}$ & $\begin{array}{l}1236(12 \%) \\
0(13.3) \\
M a x=419\end{array}$ & 0.057 & $.308^{* *}$ & -0.137 \\
\hline Medicine & 83 & $\begin{array}{l}8255(94 \%) \\
44(99.5) \\
M a x=868\end{array}$ & $\begin{array}{l}1253(59 \%) \\
2(15.1) \\
M a x=294 \\
\end{array}$ & $\begin{array}{l}626(11 \%) \\
0(7.5) \\
\text { Max=258 }\end{array}$ & $.336 * *$ & $.286 * *$ & 0.194 \\
\hline Total & 1,305 & $\begin{array}{l}82498(96 \%) \\
19(63.2) \\
\operatorname{Max}=4305\end{array}$ & $\begin{array}{l}30086(72 \%) \\
7(23.1) \\
\operatorname{Max}=294\end{array}$ & $\begin{array}{l}34663(17 \%) \\
0(26.6) \\
\operatorname{Max}=7509\end{array}$ & $.171 * *$ & $.378 * *$ & $.067 *$ \\
\hline
\end{tabular}

\section{Discussion}

Number of Amazon reviews Although 72\% of the $\mathrm{BKCl}$-indexed monographs in 2008 attracted at least one citation, only $30 \%$ had at least one review in Amazon.com. For instance, the most highly cited book in the $\mathrm{BKCl}$ dataset, 'The Migration Ecology of Birds' by lan Newton, received $339 \mathrm{BKCl}$ citations and $28 \mathrm{~GB}$ citations, but had only five Amazon book reviews. Moreover, highly cited monographs typically receive few Amazon reviews ( 9 out of 20 highly cited monographs had none - see Table 6 in the Appendix). These monographs may have been reviewed elsewhere, however, such as in academic journals (see Zuccala \& van Leeuwen, 2011). The partial coverage of English language monographs from selected publishers may also influence the results (see Torres-Salinas, 2014), and other samples (e.g., Scopus-indexed books or newer books) might give different findings.

Causes of the weak correlations between Amazon metrics and citations Despite the low number of Amazon reviews, the weak but significant correlations between Amazon metrics and both $\mathrm{BKCl}$ and $\mathrm{GB}$ citations across the three broad subject areas provides evidence that Amazon metrics might still partially reflect traditional scholarly impact (tables 2-4). One reason for the weak association might that Amazon book reviews presumably reflect to some extent the teaching impact (Kousha and Thelwall, 2008) or cultural benefit of books (White, Boell, Yu et al. 2009) rather than their impact on future research. The higher correlations between the number of Amazon reviews and WorldCat library holdings (libcitations) in arts and humanities (0.348) and social sciences (0.321) than with $\mathrm{BKCl}$ citations (0.189 and 0.223 respectively) provide some support for this argument since educational value or cultural influence of books 
might be reflected in library holdings. An alternative explanation is that both library holdings and reviews reflect the overall popularity of books.

Highly reviewed science textbooks Highly reviewed science textbooks rarely remain uncited, except for books that are published mainly for non-academics and professionals. To investigate this issue further, Scopus citations were retrieved for the 25 most highly reviewed Amazon best-selling textbooks in science and medicine. As shown in the Appendix, Table 7, many highly reviewed science textbooks have over 40 Scopus citations (11 of 25 textbooks, highlighted in bold). One example is the 'Diagnostic and Statistical Manual of Mental Disorders' (4th Edition), with 416 Amazon reviews and 6,211 Scopus and 294 GB citations, which is a standard practitioner, educational and academic reference work. Nevertheless, there are also several books with relatively many Amazon reviews but no citations in both Scopus and Google Books. For instance, 'Heal Your Headache' provides general medical information for the public but which presumably do not report primary research or any other information that is useful for researchers. Other titles (e.g., 'FE Review Manual: Rapid Preparation for the Fundamentals of Engineering Exam') are clearly for students' exam preparations and academic courses rather than for researchers. Nevertheless, Amazon metrics could also be useful to assess the value or impact of non-academic books that cannot be measured through citation metrics. For instance, the top best-selling novel in Amazon, 'The Fault in Our Stars' by John Green published in 2012 (http://www.amazon.com/The-Fault-Stars-John-Green/dp/014242417X), has attracted over 20,100 reviews (95\% of reviews with 5-4 star ratings, as of $11^{\text {th }}$ June 2014 ), whereas it had only four citations from Google Books, Scopus or Web of Science. This huge number of positive reviews can be used as an indication of the socio-cultural impact or influence of the book but literature scholars would need to decide whether it is also evidence of its academic value. Perhaps Amazon metrics could be also helpful for monitoring the impact of recently published books which may well need several years to attract formal citations. For instance, 'Hard Choices' by Hillary Rodham Clinton had received 365 (41\% with 4-5 stars) reviews in Amazon.com just two days after its publication on the 10th of June. Nevertheless, if reviews or Amazon sales ranks are to be used for this purpose then it is not clear whether publisher sales figures would be a better source if the evidence is primarily about the popularity of a work.

Cultural or teaching influence of best-selling books Although the low or insignificant correlations between Amazon book review counts and GB citations for best-selling books in most subject areas checked are not promising (except for literature and astronomy, see Table $5)$, this may be because the books have diverse intended audiences, such as academics, students or the public, and hence are not comparable in terms of their expected impacts. In education, linguistics, performing arts and engineering, many Amazon best-selling books were quite basic: about learning English (e.g., 'Understanding and Using English Grammar' by Betty Schrampfer with 107 Amazon reviews and three Scopus citations), playing music (e.g., 'Hal Leonard Guitar Method' by Will Schmid with 243 Amazon reviews and no Scopus citations) and engineering exam preparation (e.g., 'FE Review Manual' by Michael Lindeburg with 171 Amazon reviews and five Scopus citations). To check that the above titles are genuinely used in teaching, Google searches were used to identify their mentions in online syllabi or course reading lists in American educational institutions (see Kousha \& Thelwall, 2008). Manual checking of the Google results showed that the above textbooks have been recommended as reading texts in at least 35, 15 and 23 academic course syllabus in American universities or 
colleges, although these numbers are underestimates due to the exclusion of non-searchable syllabuses. In contrast, in astronomy and astrophysics there were higher significant correlations between Amazon reviews and GB citations (0.581), suggesting more similarity between the two variables. Amazon best-selling books in this category seemed to have more in-depth scientific contents that were able to be cited in other books, albeit not reporting primary research. Table 7 in the Appendix also shows that three best-selling books with high number of Amazon reviews and citations are related to astronomy and astrophysics. Although popular science books, these are also perhaps useful to academics either as concept markers for the general ideas discussed or for their broad coverage of their topics, in contrast to the narrow focus that often characterised primary research.

\section{Limitations}

The results are subject to a number of limitations. First, GB citation searches estimate book citation counts based on Google's set of searchable digitised books and heuristic filtering of search results to locate citations to books. It may be that there is a bias in Google's coverage of books and a matching bias in Amazon.com reviewers (e.g., a predominance of English books and English-speaking reviewers) that results in stronger correlations between review counts and book citations than would be obtained from other sources. The same is true for $\mathrm{BKCl}$ and Amazon reviews, although there is no specific evidence of bias in Amazon.com reviewers. Another important limitation for the best sellers results is the problem with books that are available in different editions. It is not clear whether citations or reviews should be accumulated across the different editions. Moreover, the offline identities of the reviewers have not been analysed and some may be the authors or the publishers of the book and even hostile academics seeking to undermine it. Hence, it is not known whether the book reviews contain a significant amount of spam.

The disciplinary analysis of Amazon best-selling textbooks is based on Amazon categorisations, and there may be classification errors and it is not known how Amazon performs their classifications. For instance, 'How to Read a Book: The Classic Guide to Intelligent Reading' was classified under 'Philosophy Best Seller Textbooks'. However, this book seems to be related to 'reading' and 'reading comprehension' based on its Library of Congress and WorldCat subject classifications. Finally, although the current versions of the Amazon best seller lists were used, they included books of varying ages, potentially undermining the correlation statistics.

\section{Conclusions}

This study is the first attempt to assess whether Amazon metrics reflect an aspect of the intellectual impact of books and hence could be useful for research evaluation. Based upon 2,739 BKCl-indexed monographs published in 2008, there were significant but weak correlations between Amazon review-based metrics and citation counts across the social sciences, arts and humanities, and science and medicine, despite $71 \%$ of the books having no Amazon reviews. About $72 \%$ of the $2,739 \mathrm{BKCl}$-indexed monographs published in 2008 received at least one citation in $\mathrm{BKCl}$ and $84 \%$ had at least one Google Books citation, but less than $30 \%$ had at least one review in Amazon.com. Adding the fact that Amazon reviews can be written by 
anybody and are not refereed and are vulnerable to manipulation, this suggests that reviews are of little use for the evaluation of typical academic books.

In contrast, out of 1,305 Amazon best-selling textbooks from various years, almost all (96\%) had at least one Amazon review and $72 \%$ had at least one GB citation - the latter suggesting that they have some academic merit. Significant positive correlations were also found between the number of Amazon reviews and GB citations for the best-selling textbooks in 9 out of 15 subject areas. This suggests that Amazon reviews can be used as evidence of the impact of popular academic books, although qualitative research is needed to verify this finding and to decide exactly what the various Amazon review metrics signify (e.g., review counts, average star ratings, review sentiments). This qualitative evidence is also needed because there is only indirect evidence that citations to books correlate with peer review (they correlate with citations from journal articles, and citations to journal articles have been shown to correlate with peer review).

In terms of the other metrics investigated, although they correlated significantly with citations, Mendeley bookmarks were only available for a minority of the books in both data sets ( $7 \%$ for $\mathrm{BKCl}$ and $17 \%$ for the best sellers) and so do not seem to be useful book citation impact assessment. The low WorldCat correlations with the other metrics for the $\mathrm{BKCl}$ data set, including Amazon sales ranks (perhaps because they reflect recent sales rather than total sales), is surprising and undermines to some extent previous evidence for their value from smaller datasets.

Many high impact $\mathrm{BKCl}$ scientific books attracted no online reviews in Amazon, whilst most best-selling textbooks were cited. This suggests that the number of Amazon reviews reflects the readership of a book to a much greater extent than does the number of citations to the book. Perhaps citations reflect primarily the publishing academic readership of a book or the publishing academics that read a book to learn about their publishing specialism. The bestsellers did not always aim at publishing academics but sometimes targeted the public or students. Their publishing academic readership, if any, might therefore be incidental to their main goals. Hence, it seems reasonable to claim that Amazon metrics reflect the educational uptake, general popularity or cultural influence of a book rather than its scientific impact. Thus they could be used to reflect the wider impacts of books for research evaluation purposes, but only in cases where the book authors or publishers are not incentivised (e.g., by the evaluation) to manipulate the scores of their books. This seems to be particularly important in the arts and humanities, where monographs, popular historical books and literary works (e.g., biographies, novels, poetry) are important scholarly outputs, but educational and cultural impacts and public engagement seem to be universally desirable and difficult to measure throughout academia and so online reviews may be useful throughout academia for evidence of the value of popular academic books.

\section{References}

Aksnes, D. W., \& Taxt, R. E. (2004). Peer reviews and bibliometric indicators: a comparative study at a Norwegian university. Research Evaluation, 13(1), 33-41.

Almind, T. C., \& Ingwersen, P. (1997). Informetric analyses on the World Wide Web: Methodological approaches to "Webometrics". Journal of Documentation, 53(4), 404-426. 
Association of College and Research Libraries (2011). Standards for libraries in higher education. Retrieved from http://www.ala.org/acrl/sites/ala.org.acrl/files/content/standards/slhe.pdf

Bar-Ilan, J. (2010). Citations to the "Introduction to informetrics" indexed by WOS, Scopus and Google Scholar. Scientometrics, 82(3), 495-506.

Bar-Ilan, J. (2012). JASIST@Mendeley. In ACM Web Science Conference 2012 Workshop. Retrieved from http://altmetrics.org/altmetrics12/bar-ilan/

Bar-Ilan, J., Haustein, S., Peters, I., Priem, J., Shema, H., \& Tersliesner, J. (2012). Beyond citations: Scholars' visibility on the social Web. In E. Archambault., Y. Gingras \& V. Larivière (Eds.), Proceedings of 17th International Conference on Science and Technology Indicators, (pp. 98-109). Montréal: Science-Metrix and OST.

Bell, R. L., \& Bodie, N. (2012). Leaders as Catalysts for Organizational Change: How Popular Press Business Books Address this Topic. Journal of Organizational Culture, Communications and Conflict, 16(1), 49-70.

Bence, V., \& Oppenheim, C. (2004). The influence of peer review on the research assessment exercise. Journal of Information Science, 30(4), 347-368.

Bollen, J., Van De Sompel, H., Smith, J. A., \& Luce, R. (2005). Toward alternative metrics of journal impact: A comparison of download and citation data. Information Processing \& Management, 41(6), 1419-1440.

Brody, T., Harnad, S., \& Carr, L. (2006). Earlier web usage statistics as predictors of later citation impact. Journal of the American Society for Information Science and Technology, 57(8).

Butler, L., \& Visser, M. (2006). Extending citation analysis to non-source items. Scientometrics, 66(2), 327-343.

Cabezas-Clavijo, A., Robinson-García, N., Torres-Salinas, D., Jiménez-Contreras, E., Mikulka, T., Gumpenberger, C., Wemisch, A., \& Gorraiz, J. (2013). Most borrowed is most cited? Library loan statistics as a proxy for monograph selection in citation indexes. In: Proceedings of 14th International Conference of the International Society for Scientometrics and Informetrics, Vienna, Austria, Vol. 2, pp. 1237-1252. Retrieved from http://arxiv.org/ftp/arxiv/papers/1305/1305.1488.pdf.

Calhoun, K. (2006). The changing nature of the catalog and its integration with other discovery tools. Prepared for the Library of Congress. Retrieved from http://works.bepress.com/cgi/viewcontent.cgi?article=1005\&context=karen_calhoun

Chen, P., Dhanasobhon, S., \& Smith, M. (2008). All reviews are not created equal: The disaggregate impact of reviews and reviewers at Amazon.Com. Retrieved from http://ssrn.com/abstract $=918083$

Chevalier, J. A., \& Mayzlin, D. (2006). The effect of word of mouth on sales: Online book reviews. Journal of Marketing Research, 43(3), 345-354.

Chubin, D. E., \& Moitra, S. D. (1975). Content analysis of references: adjunct or alternative to citation counting? Social Studies of Science, 5(4), 423-441.

Costas, R., Zahedi, Z., \& Wouters, P. (2014). Do altmetrics correlate with citations? Extensive comparison of altmetric indicators with citations from a multidisciplinary perspective. Retrieved from http://arxiv.org/abs/1401.4321v1

Cronin, B., Snyder, H. \& Atkins, H. (1997). Comparative citation rankings of authors in monographic and journal literature: A study of sociology. Journal of Documentation, 53(3), 263-273. 
Cronin, B., Snyder, H. W., Rosenbaum, H., Martinson, A., \& Callahan, E. (1998). Invoked on the Web. Journal of the American Society for Information Science, 49(14), 1319-1328.

Cullars, J. (1998). Citation characteristics of English-language monographs in philosophy. Library \& Information Science Research, 20(1), 41-68.

Dilevko, J., McMillan, B., Allison-Cassin, S., Aspinall, J., \& Mauro, C. (2006). Investigating the value of scholarly book reviews for the work of academic reference librarians. Journal of Academic Librarianship, 32(5), 452-466.

Donovan, C., \& Butler, L. (2007). Testing novel quantitative indicators of research "quality," esteem and "user engagement:" An economics pilot study. Research Evaluation, 16, 231242.

Engels, T. C., Ossenblok, T. L., \& Spruyt, E. H. (2012). Changing publication patterns in the Social Sciences and Humanities, 2000-2009. Scientometrics, 93(2), 373-390.

Eysenbach, G. (2011). Can tweets predict citations? Metrics of social impact based on twitter and correlation with traditional metrics of scientific impact. Journal of Medical Internet Research, 13(4).

Forman, C., Ghose, A., \& Wiesenfeld, B. (2008). Examining the relationship between reviews and sales: The role of reviewer identity disclosure in electronic markets. Information Systems Research, 19(3), 291-313.

Franceschet, M., \& Costantini, A. (2011). The first Italian research assessment exercise: A bibliometric perspective. Journal of Informetrics, 5(2), 275-291.

Garfield, E. (1996). Citation indexes for retrieval and research evaluation. Consensus Conference on the Theory and Practice of Research Assessment, Capri. Retrieved from http://www.garfield.library.upenn.edu/papers/ciretreseval-capri.html

Glänzel, W., \& Schoepflin, U. (1999). A bibliometric study of reference literature in the sciences and social sciences. Information Processing \& Management, 35(1), 31-44.

Garand, J.C., \& Giles, M.W. (2011). Ranking scholarly publishers in political science: An alternative approach. PS: Political Science and Politics, 44(2), 375-383.

Giménez-Toledo, E., \& Román, A. (2008). Peer review and in-depth interviews with publishers as a means of assessing quality of research monographs. 10th International Conference on Science and Technology Indicators, Vienna (Austria). Retrieved from http://eprints.rclis.org/handle/10760/12337.

Giménez-Toledo, E., Tejada-Artigas, C., \& Mañana-Rodríguez, J. (2013). Evaluation of scientific books' publishers in social sciences and humanities: Results of a survey. Research Evaluation, 22(1), 64-77.

Gorraiz, J., Gumpenberger, C., \& Purnell, P. J. (2014). The power of book reviews: A simple and transparent enhancement approach for book citation indexes. Scientometrics, 98(2), 841852.

Gorraiz, J., Purnell, P. J., \& Glänzel, W. (2013). Opportunities for and limitations of the book citation index. Journal of the American Society for Information Science and Technology, 64(7), 1388-1398.

Hammarfelt, B. (in press, 2014). Using altmetrics for assessing research impact in the humanities. Scientometrics. DOI: 10.1007/s11192-014-1261-3. Retrieved from http://uu.diva-portal.org/smash/get/diva2:703046/FULLTEXT01.pdf 
Hartley, J. (2006). Reading and writing book reviews across the disciplines. Journal of the American Society for Information Science and Technology, 57(9), 1194-1207.

Hicks, D. (1999). The difficulty of achieving full coverage of international social science literature and the bibliometric consequences. Scientometrics, 44(2), 193-215.

Hicks, D. (2012). Performance-based university research funding systems. Research Policy, 41(2), 251-261.

Huang, M., \& Chang, Y. (2008). Characteristics of research output in social sciences and humanities: from a research evaluation perspective. Journal of the American Society for Information Science and Technology, 59(11), 1819-1828.

Kousha, K., \& Thelwall, M. (2008). Assessing the impact of disciplinary research on teaching: An automatic analysis of online syllabuses. Journal of the American Society for Information Science and Technology, 59(13), 2060-2069.

Kousha, K., \& Thelwall, M. (2009). Google book search: Citation analysis for social science and the humanities. Journal of the American Society for Information Science and Technology, 60(8), 1537-1549.

Kousha, K., Thelwall, M., \& Rezaie, S. (2011). Assessing the citation impact of books: The role of Google Books, Google Scholar, and Scopus. Journal of the American Society for Information Science and Technology, 62(11), 2147-2164.

Kousha, K., \& Thelwall, M. (2014). An automatic method for extracting citations from Google Books. Journal of the Association for Information Science and Technology. doi: $10.1002 / a s i .23170$

Krampen, G., Becker, R., Wahner, U., \& Montada, L. (2007). On the validity of citation counting in science evaluation: Content analyses of references and citations in psychological publications. Scientometrics, 71(2), 191-202.

Larviere,V., Archambault, E., Gingras,Y., \& Vignola-Gagne, E. (2006). The place of serials in referencing practices: Comparing natural sciences and engineering with social sciences and humanities. Journal of the American Society for Information Science and Technology, 57(8), 997-1004.

Leino, J., \& Räihä, K. (2007). Case Amazon: Ratings and reviews as part of recommendations. Proceedings of the 2007 ACM Conference on Recommender Systems, October 19-20, 2007, Minneapolis, Minnesota, USA 137-140. Retrieved from https://www.macs.hw.ac.uk/ dwcorne/ACMRecSys07/p137-leino.pdf

Leydesdorff, L., \& Felt, U. (2012). Edited volumes, monographs and book chapters in the Book Citation Index $(\mathrm{BKCl})$ and Science Citation Index $(\mathrm{SCl}, \mathrm{SoSCl}, \mathrm{A} \& \mathrm{HCl})$. Journal of Scientometric Research, 1(1), 28-34.

Li, X., \& Thelwall, M. (2012). F1000, Mendeley and traditional bibliometric indicators. In É. Archambault, Y. Gingras \& V. Larivière (Eds.), 17th international conference on science and technology indicators (STI 2012) (pp. 541-551). Montréal: Science-Metrix and OST.

Li, X., Thelwall, M., \& Giustini, D. (2012). Validating online reference managers for scholarly impact measurement. Scientometrics, 91(2), 461-471.

Lindholm-Romantschuk, Y., \& Warner, J. (1996). The role of monographs in scholarly communication: An empirical study of philosophy, sociology and economics. Journal of Documentation, 52(4), 389-404. 
Linmans, A. J. M. (2010). Why with bibliometrics the humanities does not need to be the weakest link. Scientometrics, 83(2), 337-354.

MacRoberts, M., \& MacRoberts, B. (1996). Problems of citation analysis. Scientometrics, 36(3), 435-444.

MacRoberts, M. H., \& MacRoberts, B. R. (2010). Problems of citation analysis: A study of uncited and seldom-cited influences. Journal of the American Society for Information Science and Technology, 61(1), 1-12.

Metz, P., \& Stemmer, J. (1996). A reputational study of academic publishers. College and Research Libraries, 57(3), 234-247.

Mohammadi, E., \& Thelwall, M. (2014). Mendeley readership altmetrics for the social sciences and humanities: Research evaluation and knowledge flows. Journal of the Association for Information Science and Technology. doi: 10.1002/asi.23071

Myers, G. (1991). Lexical cohesion and specialized knowledge in science and popular science texts. Discourse Processes, 14(1), 1-26.

Nederhof, A. (2006). Bibliometric monitoring of research performance in the social sciences and the humanities: A review. Scientometrics, 66(1), 81-100.

Nederhof, A., \& van Raan, A. (1993). A bibliometric analysis of six economics research groups: A comparison with peer review. Research Policy, 22(4), 353-368.

Nicolaisen, J. (2002). The J-shaped distribution of citedness. Journal of Documentation, 58(4), 383-395.

Norris, M., \& Oppenheim, C. (2003). Citation counts and the Research Assessment Exercise V: Archaeology and the 2001 RAE. Journal of Documentation, 59(6), 709-730.

O'Neill, E. T., Connaway, L. S., \& Dickey, T. J. (2008). Estimating the audience level for library resources. Journal of the American Society for Information Science and Technology, 59(13), 2042-2050.

Oikkonen, V. (2013). Competing Truths: Epistemic authority in popular science books on human sexuality. European Journal of English Studies, 17(3), 283-294.

Oppenheim, C. (2000). Do patent citations count?. In: Cronin, B. and Atkins, H. B. (eds.). The web of knowledge: a festschrift in honor of Eugene Garfield. Metford, NJ: Information Today Inc. (pp. 405-432).

Oppenheim, C. (1995). The correlation between citation counts and the 1992 Research Assessment Exercise Ratings for British library and information science university departments. Journal of Documentation, 51(1), 18-27.

Oppenheim, C. (1997). The correlation between citation counts and the 1992 research assessment exercise ratings for British research in genetics, anatomy and archaeology. Journal of Documentation, 53(5), 477-487.

Palmer, M. (2005). Scholarly work and the shaping of digital access, Journal of the American Society for Information Science and Technology, 56(11), 1140-1153.

Pang, B., \& Lee, L. (2008). Opinion mining and sentiment analysis. Foundations and Trends in Information Retrieval, 2(1-2), 1-135.

Porta, M., Fernandez, E., \& Puigdomènech, E. (2006). Book citations: Influence of epidemiologic thought in the academic community. Revista De Saude Publica, 40(SPEC. ISS.), 50-56.

Priem, J. (2014). Altmetrics. In: Cronin, B. \& Sugimoto, C., editors. Bibliometrics and beyond: Metrics-based evaluation of scholarly research, Cambridge: MIT Press. 
Rinia, E. J., van Leeuwen, T. N., van Vuren, H. G., \& van Raan, A. F. (1998). Comparative analysis of a set of bibliometric indicators and central peer review criteria: Evaluation of condensed matter physics in the Netherlands. Research Policy, 27(1), 95-107.

Shaw, D. (1991). An analysis of the relationship between book reviews and fiction holdings in OCLC. Library and Information Science Research, 13(2), 147-154.

Shema, H., Bar-Ilan, J., \& Thelwall, M. (2013). Do blog citations correlate with a higher number of future citations? (RIP). Paper presented at the Proceedings of ISSI 2013 - 14th International Society of Scientometrics and Informetrics Conference, (pp. 604-611).

Shen, W., Yu, J., \& Rees, J. (2009). Competing for attention: An empirical study of online reviewers' strategic behaviors, Proceedings of the 14th Conference on Information Systems \& Technology (CIST), San Diego, October 10-11. Retrieved from https://www.krannert.purdue.edu/academics/MIS/workshop/papers/WS_02032012.pdf

Spink, A., Robins, D., \& Schamber, L. (1998). Use of scholarly book reviews: Implications for electronic publishing and scholarly communication. Journal of the American Society for Information Science, 49(4), 364-374.

Sud, P. \& Thelwall, M. (2014). Evaluating altmetrics. Scientometrics, 98(2),1131-1143.

Taylor, J., \& Walker, I. (2009). Peer assessment of research: how many publications per staff? Lancaster University Management School, Working Paper 2009/035. Retrieved from http://eprints.lancs.ac.uk/48977/1/Document.pdf

Testa, J. (2011). The book selection process for the Book Citation Index in Web of Science. Retrieved from http://wokinfo.com/media/pdf/BKCl-SelectionEssay_web.pdf

The Book Citation Index. from http://wokinfo.com/products_tools/multidisciplinary/bookcitationindex/

Thelwall, M., Buckley, K., \& Paltoglou, G. (2012). Sentiment strength detection for the social Web, Journal of the American Society for Information Science and Technology, 63(1), 163173.

Thelwall, M., Buckley, K., Paltoglou, G. Cai, D., \& Kappas, A. (2010). Sentiment strength detection in short informal text. Journal of the American Society for Information Science and Technology, 61(12), 2544-2558.

Thelwall, M., Haustein, S., Larivière, V., \& Sugimoto, C. R. (2013). Do altmetrics work? Twitter and ten other social web services. PLoS ONE, 8(5), e64841.

Thompson, J. (2002).The death of the scholarly monograph in the humanities? Citation patterns in literary scholarship. Libri, 52, 121-136.

Torres-Salinas, D., \& Moed, H.F. (2008). Library catalog analysis is a useful tool in studies of social sciences and humanities. In Excellence and emergence. A new challenge for the combination of quantitative and qualitative approaches (pp. 246-250). Proceedings of the 10th International Conference on Science and Technology Indicators, Vienna, Austria.

Torres-Salinas, D., \& Moed, H. F. (2009). Library catalog analysis as a tool in studies of social sciences and humanities: An exploratory study of published book titles in economics. Journal of Informetrics, 3(1), 9-26.

Torres-Salinas, D., Robinson-García, N., Campanario, J. M., \& López-Cózar, E. D. (2014). Coverage, field specialisation and the impact of scientific publishers indexed in the book citation index. Online Information Review, 38(1), 24-42. 
Torres-Salinas, D., Robinson-García, N., Jiménez-Contreras, E. \& Delgado López-Cózar, E. (2012). Towards a 'Book Publishers Citation Reports'. First approach using the 'Book Citation Index'. Revista Española de Documentación Científica, 35(4), 615-620.

Torres-Salinas, D., Rodríguez-Sánchez, R., Robinson-García, N., Fdez-Valdivia, J., \& García, J. A. (2013). Mapping citation patterns of book chapters in the Book Citation Index. Journal of Informetrics, 7(2), 412-424.

van Raan, A. F. J. (2006). Comparison of the Hirsch-index with standard bibliometric indicators and with peer judgment for 147 chemistry research groups. Scientometrics, 67(3), 491-502.

Verleysen, F. T., \& Engels, T. C. E. (2013). A label for peer-reviewed books. Journal of the American Society for Information Science and Technology, 64(2), 428-430.

Warner, J. (2000). A critical review of the application of citation studies to the Research Assessment Exercises. Journal of Information Science, 26(6), 453-459.

White, H. D., Boell, S. K., Yu, H., Davis, M., Wilson, C. S., \& Cole, F. T. H. (2009). Libcitations: A measure for comparative assessment of book publications in the humanities and social sciences. Journal of the American Society for Information Science and Technology, 60(6), 1083-1096.

Williams, P., Stevenson, I., Nicholas, D., Watkinson, A., \& Rowlands, I. (2009). The role and future of the monograph in arts and humanities research. Aslib Proceedings, 61(1), 67-82.

Wouters, P., \& Costas, R. (2012). Users, narcissism and control - Tracking the impact of scholarly publications in the 21st century. Utrecht: SURF-foundation. Retrieved from http://research-acumen.eu/wp-content/uploads/Users-narcissism-and-control.pdf

Wu, P. F, Van Der Heijden, H., \& Korfiatis, N. T. (2011). The influences of negativity and review quality on the helpfulness of online reviews. Paper presented at the International Conference on Information Systems 2011, ICIS 2011, 5 3710-3719.

Wu, W., \& Zheng, R. (2012). The impact of word-of-mouth on book sales: Review, blog or tweet? Paper presented at the ACM International Conference Proceeding Series, August 0708, Singapore, Singapore, 74-75.

Zahedi, Z., Costas, R., \& Wouters, P. (in press, 2014). How well developed are altmetrics? A cross-disciplinary analysis of the presence of 'alternative metrics' in scientific publications. Scientometrics. DOI: 10.1007/s11192-014-1264-0. Retrieved from http://arxiv.org/ftp/arxiv/papers/1404/1404.1301.pdf

Zuccala, A., \& Guns, R. (2013). Comparing book citations in humanities journals to library holdings: Scholarly use versus 'perceived cultural benefit' (RIP). Paper presented at the Proceedings of ISSI 2013 - 14th International Society of Scientometrics and Informetrics Conference (pp. 353-360).

Zuccala, A., Guns, R., Cornacchia, R., \& Bod, R. (in press, 2014). Can we rank scholarly book publishers? A bibliometric experiment with the field of history. Journal of the Association for Information Science and Technology. Retrieved from http://www.illc.uva.nl/evaluatinghumanities/RankPublishers(Mar5_2014Preprint).pdf

Zuccala, A., \& van Leeuwen, T. (2011). Book reviews in humanities research evaluations. Journal of the American Society for Information Science and Technology, 62(10), 1979-1991.

Zuccala, A., van Someren, M., \& van Bellen, M. (in press, 2014). A machine-learning approach to coding book reviews as quality indicators: Toward a theory of megacitation. Journal of the Association for Information Science and Technology. doi: 10.1002/asi.23104 


\section{Appendix}

Table 6. Metric scores for the 20 most highly cited BKCl-indexed monographs (April 2014).

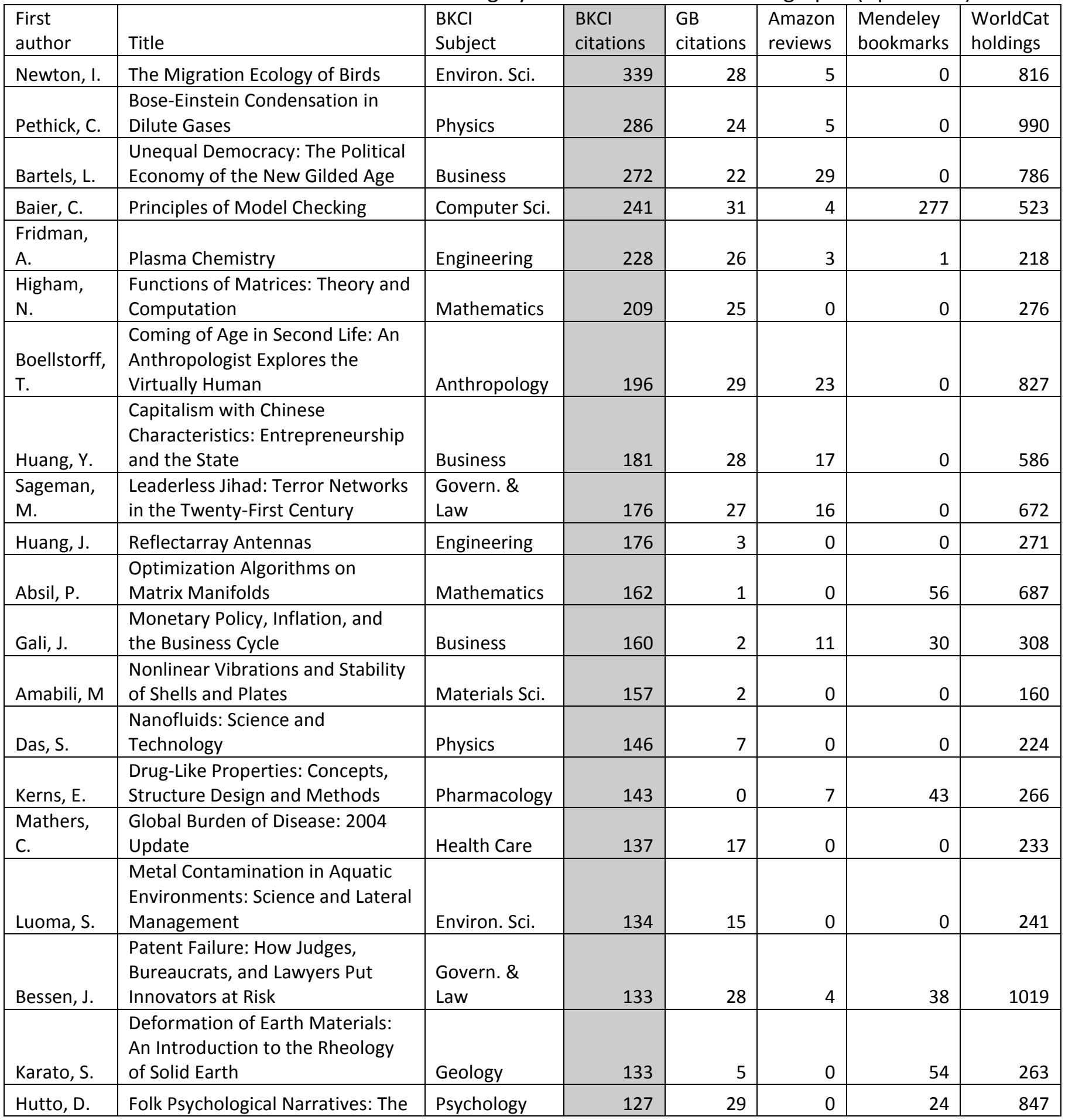


Sociocultural Basis of

Understanding Reasons

Table 7. Top 25 Best-selling Amazon textbooks in science and medicine in terms of the number of Amazon customer reviews (May 2014).

\begin{tabular}{|c|c|c|c|c|c|c|}
\hline First author & Title & $\begin{array}{l}\text { Amazon } \\
\text { Reviews }\end{array}$ & $\begin{array}{l}\text { GB } \\
\text { citations }\end{array}$ & $\begin{array}{l}\text { Scopus } \\
\text { citation* }\end{array}$ & $\begin{array}{l}\text { Mendeley } \\
\text { bookmarks }\end{array}$ & $\begin{array}{l}\text { Amazon } \\
\text { subject }\end{array}$ \\
\hline Roach, M. & Stiff: The Curious Lives of Human Cadavers & 868 & 16 & 41 & 0 & $\begin{array}{l}\text { Biology \& Life } \\
\text { Sciences }\end{array}$ \\
\hline $\begin{array}{l}\text { Mukherjee, } \\
\text { S. }\end{array}$ & $\begin{array}{l}\text { The Emperor of All Maladies: A Biography of } \\
\text { Cancer }\end{array}$ & 759 & 22 & 104 & 0 & Medicine \\
\hline Krauss, L. & $\begin{array}{l}\text { A Universe from Nothing: Why There Is } \\
\text { Something Rather than Nothing }\end{array}$ & 592 & 19 & 8 & 1 & \\
\hline Dawkins, R. & $\begin{array}{l}\text { The Greatest Show on Earth: The Evidence } \\
\text { for Evolution }\end{array}$ & 490 & 27 & 95 & 0 & $\begin{array}{l}\text { Biology \& Life } \\
\text { Sciences }\end{array}$ \\
\hline Buchholz, D & Heal Your Headache & 466 & 5 & 0 & 0 & Medicine \\
\hline Dubin, D. & Rapid Interpretation of EKG's & 427 & 25 & 71 & 0 & Medicine \\
\hline $\begin{array}{l}\text { American } \\
\text { Psychiatric } \\
\text { Association }\end{array}$ & $\begin{array}{l}\text { Diagnostic and Statistical Manual of Mental } \\
\text { Disorders }\end{array}$ & 416 & 294 & 6,211 & 108 & Medicine \\
\hline Sagan, C. & Cosmos & 333 & 157 & 118 & 0 & $\begin{array}{l}\text { Astronomy \& } \\
\text { Astrophysics }\end{array}$ \\
\hline $\begin{array}{l}\text { Christensen, } \\
\text { L. }\end{array}$ & $\begin{array}{l}\text { On Combat, The Psychology and Physiology } \\
\text { of Deadly Conflict in War and in Peace }\end{array}$ & 320 & 3 & 26 & 0 & $\begin{array}{l}\text { Biology \& Life } \\
\text { Sciences }\end{array}$ \\
\hline Gawande, A. & $\begin{array}{l}\text { Complications: A Surgeon's Notes on an } \\
\text { Imperfect Science }\end{array}$ & 305 & 32 & 201 & 0 & Medicine \\
\hline Carson, $\mathbf{R}$. & Silent Spring & 291 & 158 & 2,414 & 0 & $\begin{array}{l}\text { Environment } \\
\text { al Studies }\end{array}$ \\
\hline $\begin{array}{l}\text { Kharrazian, } \\
\text { D. }\end{array}$ & $\begin{array}{l}\text { Why Do I Still Have Thyroid Symptoms? when } \\
\text { My Lab Tests Are Normal: a Revolutionary } \\
\text { Breakthrough in Understanding Hashimoto's } \\
\text { Disease and Hypothyroidism }\end{array}$ & 290 & 0 & 0 & 0 & Medicine \\
\hline Mace, $\mathrm{N}$. & $\begin{array}{l}\text { The 36-Hour Day: A Family Guide to Caring } \\
\text { for People Who Have Alzheimer Disease, } \\
\text { Related Dementias, and Memory Loss }\end{array}$ & 287 & 0 & 0 & 0 & Medicine \\
\hline Kurzweil. R. & $\begin{array}{l}\text { The Singularity Is Near: When Humans } \\
\text { Transcend Biology }\end{array}$ & 267 & 37 & 693 & 58 & $\begin{array}{l}\text { Biology \& Life } \\
\text { Sciences }\end{array}$ \\
\hline $\begin{array}{l}\text { Campbell- } \\
\text { McBride, N. }\end{array}$ & $\begin{array}{l}\text { Gut and Psychology Syndrome: Natural } \\
\text { Treatment for Autism }\end{array}$ & 265 & 4 & 5 & 4 & Medicine \\
\hline England. P. & $\begin{array}{l}\text { Birthing from Within: An Extra-Ordinary } \\
\text { Guide to Childbirth Preparation }\end{array}$ & 257 & 24 & 12 & 0 & Medicine \\
\hline $\begin{array}{l}\text { Wasserman, } \\
\text { S. }\end{array}$ & Campbell Biology & 221 & 12 & 34 & 135 & $\begin{array}{l}\text { Biology \& Life } \\
\text { Sciences }\end{array}$ \\
\hline Penrose, $\mathbf{R}$. & $\begin{array}{l}\text { The Road to Reality: A Complete Guide to } \\
\text { the Laws of the Universe }\end{array}$ & 219 & 39 & 236 & 0 & $\begin{array}{l}\text { Astronomy \& } \\
\text { Astrophysics }\end{array}$ \\
\hline Alberts, B. & Molecular Biology of the Cell & 210 & 164 & 9348 & 67 & $\begin{array}{l}\text { Biology \& Life } \\
\text { Sciences }\end{array}$ \\
\hline Platt, C. & Make: Electronics & 189 & 0 & 0 & 0 & Engineering \\
\hline Netter, F. & Atlas of Human Anatomy: with Student & 172 & 1 & 0 & 0 & Medicine \\
\hline
\end{tabular}




\begin{tabular}{|l|l|l|l|l|l|l|}
\hline & Consult Access & & & & \\
\hline Lindeburg, M. & $\begin{array}{l}\text { FE Review Manual: Rapid Preparation for the } \\
\text { Fundamentals of Engineering Exam }\end{array}$ & 171 & 0 & 0 & 0 & Engineering \\
\hline $\begin{array}{l}\text { Langewiesch } \\
\text { e, W. }\end{array}$ & $\begin{array}{l}\text { Stick and Rudder: An Explanation of the Art of } \\
\text { Flying }\end{array}$ & 164 & 27 & 16 & 0 & Engineering \\
\hline Deutsch, D. & $\begin{array}{l}\text { The Fabric of Reality: The Science of Parallel } \\
\text { Universes }\end{array}$ & 146 & $\mathbf{3 6}$ & $\mathbf{4 8}$ & 22 & $\begin{array}{l}\text { Astronomy \& } \\
\text { Astrophysics }\end{array}$ \\
\hline Wallach, J & Dead Doctors Don't Lie & 138 & 0 & 0 & 0 & Medicine \\
\hline
\end{tabular}

